Paper telah diterbitkan dalam jurnal KEGURU edisi februari 2018. http://jurnal.stkippgribkl.ac.id/index.php/KGU/article/view/335

ISSN 2579-9886 (Cetak)

\title{
Pengaruh Model Pembelajaran Make a Match terhadap Hasil Belajar Siswa Di Kelas VII SMP Yapis Manokwari
}

\author{
Mohamad Khoirul Munir \\ Jurusan Pendidikan Biologi, FKIP, UNIPA \\ mohamadmunir1607@gmail.com \\ Insar Damopolii \\ Jurusan Pendidikan Biologi, FKIP, UNIPA \\ i.damopoli@unipa.ac.id \\ Iwan \\ Jurusan Pendidikan Biologi, FKIP, UNIPA \\ b.iwan@unipa.ac.id
}

\begin{abstract}
The purpose of the study was to find out different cognitive student achievement used Make a Match and conventional learning model in pollution and destruction environment and the connection with human activity material in class VII SMP Yapis Manokwari. The method used the quasi experimental with nonequivalent control group design. The sample in this research was conducted in class VIII $A$ as experimental class as many as 28 students and class VII B as control class as many as 25 students. The technique sampling used purposive sampling. The data analysis was $t$-test and significant $a=0,05$. The result showed the significant 0,039<0,05 and score of experiment class were 69,21 and control class were 56,4. Conclusion, there is a significant difference in the average cognitive student achievement who are taught by Make a Match learning model and the conventional learning model.
\end{abstract}

Keywords: Make a Match learning model, conventional learning model, cognitive student achievement

\begin{abstract}
Abstrak
Penelitian bertujuan untuk menemukan perbedaan hasil belajar kognitif siswa menggunakan model pembelajaran Make a Match dan konvensional pada materi pencemaran dan kerusakan lingkungan hubungannya dengan aktivitas manusia di kelas VII SMP Yapis Manokwari. Metode penelitian menggunakan kuasi eksperimen dengan nonequivalent control group design. Sampel dalam penelitian ini adalah siswa kelas VII A sebagai kelas eksperimen dengan jumlah 28 siswa dan kelas VII B sebagai kelas kontrol dengan jumlah 25 siswa. Pengambilan sampel menggunakan sampel bertujuan. Analisis data menggunakan uji t pada taraf signifikan 0,05. Hasil penelitian menunjukkan nilai signifikan 0,039 < 0,05 dan skor kelas eksperimen sebesar 69,21 dan kelas kontrol 56,4. Kesimpulan, terdapat perbedaan yang signifikan antara rata-rata hasil belajar cognitif siswa yang diajarkan dengan model pembelajaran Make a Match dan model pembelajaran konvensional.
\end{abstract}

Kata Kunci: Model pembelajaran Make a Macth, model pembelajaran konvensional, hasil belajar kognitif 